\title{
STUDY ON BOULDERS OF MEGALITH 3 AT THE WIETRZYCHOWICE SITE (CENTRAL POLAND)
}

\author{
MACIE] PAWLIKOWSKI ${ }^{1}$, MACIE] JARANOWSKI ${ }^{2}$, PIOTR PAPIERNIK ${ }^{3}$
}

\begin{abstract}
Boulders from Wietrzychowice megaliths underwent geological, mineralogical and petrographic study. Pink and grey granitoids were more numerous than other types of erratic stones. Boulders used in building the stone walls of the megalith's construction had been processed by means of "flaking" technique, rock-cutting technology, mixed "flaking" and rockcutting technologies, and by drilling. Initial research has revealed the presence of Cretaceous and Jurassic flint stones in glaciofluvial gravel in the vicinity of the site. They underwent preliminary technological, mineralogical and geochemical analysis. The research was conducted by means of modern mineralogical methods, including polarised and scanning microscopy and atomic absorption spectroscopy.
\end{abstract}

Key words: Kuyavia, Wietrzychowice, mineralogical and petrographic research, long barrows

\section{Introduction}

The Wietrzychowice site is situated in the southern part of the Kuyavian Lakeland (Fig. 1) in the close vicinity of the Last Glacial Maximum (LGM) (Roman 2010). It is therefore located within the recently glaciated area of the Weichselian Glaciation. The geological structure of the site surroundings is formed mostly by sands with gravels and silty sands of glaciofluvial plains, and by the glacial till of morainic plateaus. Roman $(2003,2010)$ has recorded the presence of the Kuyavian Lakeland's only horizon of basal till of the Weichselian glaciationin, with a thickness of 2-5 m. The Wietrzychowice site is situated on the surface of a glaciofluvial plain in the immediate vicinity of a very narrow tunnel valley, oriented NNE-SSW, which is filled with lacustrine and peat deposits (Kittel 2017).

The first published information on Kuyavian long barrows of the Funnel Beaker Culture people at Wietrzychowice appeared in the 1930s and was based on the results of initial excavation works conducted by Jażdżewski (1936a, b). The publications resumed in the 1970s (Jadczykowa $1970,1971)$ and further research has been carried out by Papiernik (2016; Papiernik, Płaza 2017). The archaeological research has been completed in recent years by geological, geomorphological and geoarchaeological studies (Kittel 2017). As a part of those, detailed mineralogical and petrographical analyses of boulders from the megalith constructions No. 3 were undertaken by Jaranowski (2019). The results obtained are presented in the current paper.

The paper is aimed at: (1) establishing the petrographic composition of the construction of megalith boulders surrounding the long barrows; (2) comparing the obtained results with the analyses of the petrographic composition of Scandinavian erratic stones in the surrounding area; (3) working out possible traces and types of the processing of boulders; (4) preliminary recognition of local flint stones as the raw material used in the production of flint tools.

\footnotetext{
${ }^{1}$ AGH - University of Science and Technology, Department of Mineralogy, Petrography and Geochemistry, al. Mickiewicza 30, 30-059 Kraków, Poland; e-mail: mpawlik@agh.edu.pl, ORCID: 0000-001-8604-7552

${ }^{2}$ Polish Academy of Sciences, Institute of Geological Sciences, Research Institute of Kraków, ul. Senacka 1, 31-002 Kraków, Poland; e-mail: m.d.jaranowski@interia.pl

${ }^{3}$ Museum of Archaeology and Ethnography in Lodz, Plac Wolności 14, 91-415 Łódź, Poland; e-mail: piotr.papiernik@maie.lodz.pl, ORCID: 0000-0002-0970-5627
} 


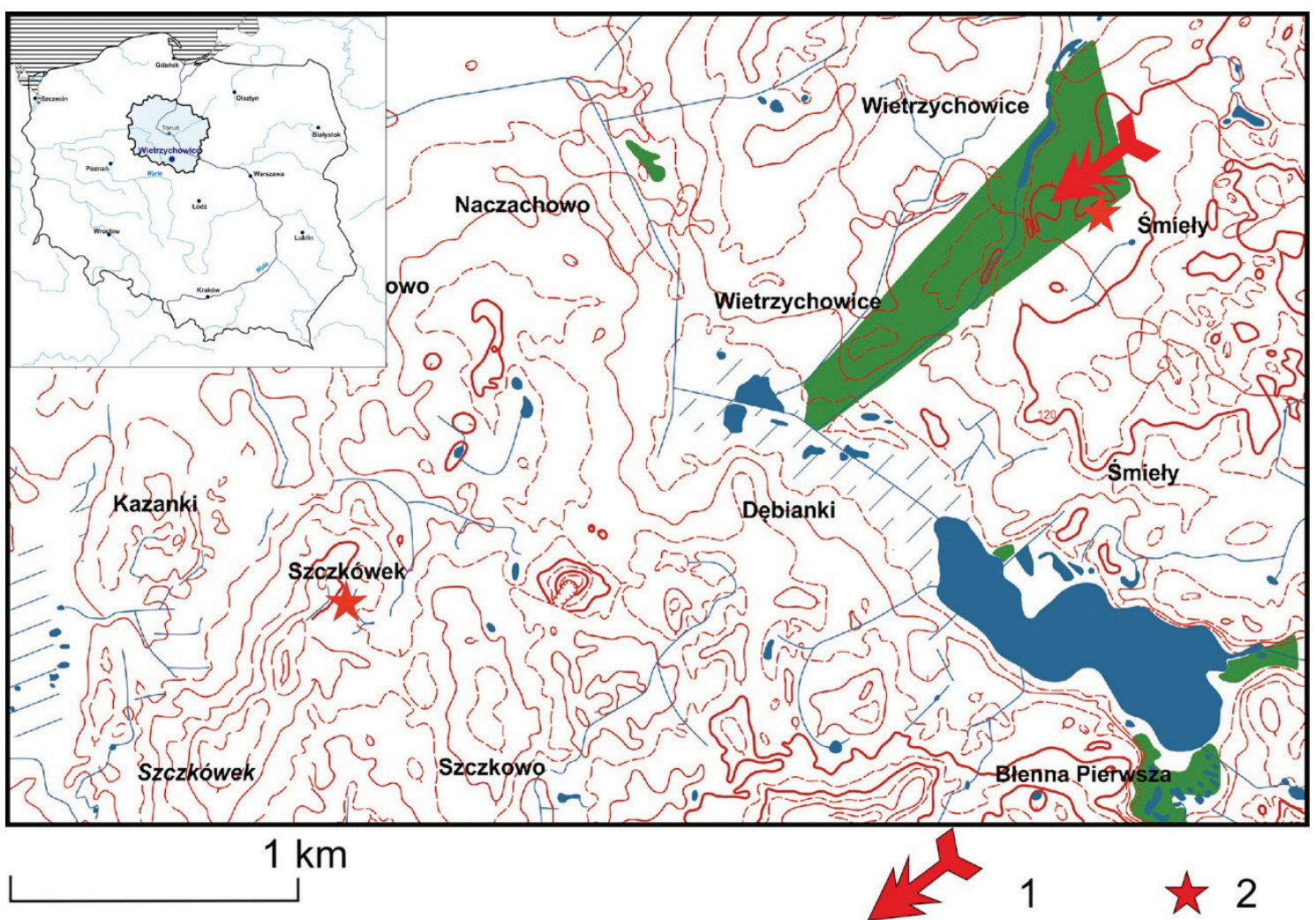

Fig. 1. Study area

1 - location of Wietrzychowice site, 2 - field works on Cretaceous and Jurassic flint stones

\section{Material and methods}

Boulders that surrounded the Wietrzychowice long barrows underwent specialised mineralogical and petrographical examination. Long barrow 3 (Fig. 2) deserves special attention, as the results of its exploration are presented in this publication. The macroscopic analysis of boulders of long barrow 3 at Wie- trzychowice was undertaken in May 2018. Following the observation of flat, "cut" surfaces of boulders from the Wietrzychowice long barrows, detailed examination of the traces of rock cutting was made. The surfaces of the obtained micro flakes with traces of cutting were first observed through a binocular microscope, and then the selected samples underwent scanning examination.

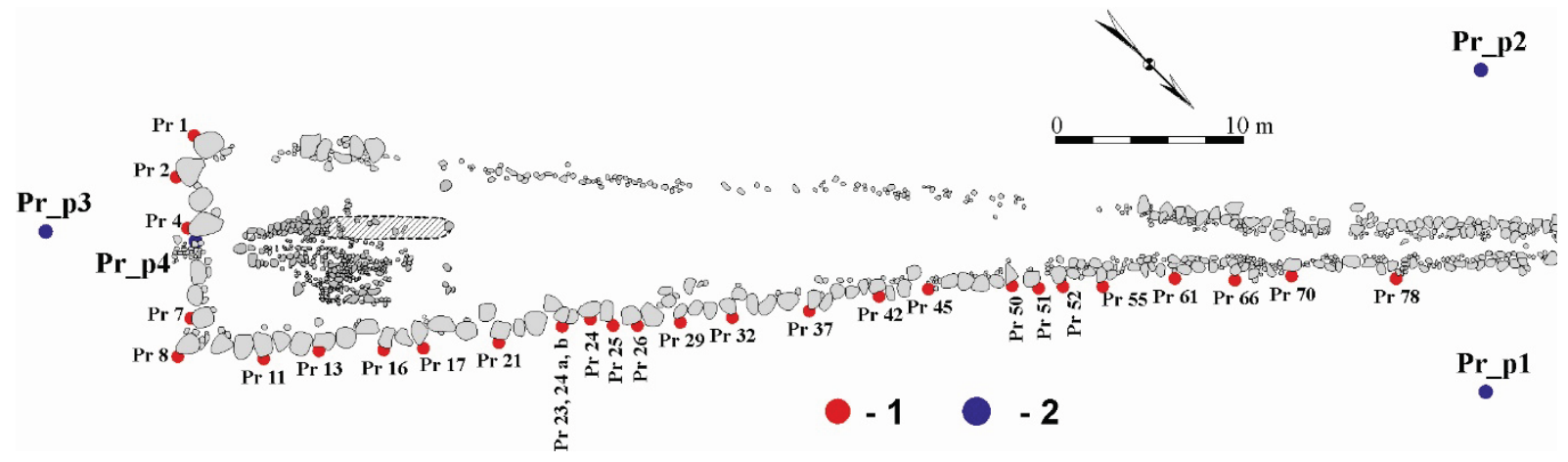

Fig. 2. Sketch of long barrow No. 3

1 - numbers of studied boulders of the stone wall construction, 2 - points of sampling of sediments surrounding tombs 
Before microscopic observations, the samples were cleaned of algae and moss prior to the microscope examination. The cleaning was performed by means of perhydrol diluted in distilled water in the proportion 1:1. After cleaning, the sample was rinsed twice in distilled water and then dried at $100^{\circ} \mathrm{C}$. Then the samples were cooled and prepared for research by drying in a vacuum.

The research samples were studied using a PZO (Polish Optical Industries) binocular microscope. The research was documented with the use of microphotographs. Polished surfaces of the studied boulders were examined under a Motic polarising microscope. In this case, too, the research was documented by means of microphotographs.

Selected rock samples underwent analysis with an FEI QUANTA 200 FEG scanning microscope. Observations and chemical analyses were carried out in the micro-zone of the studied samples.

The examination of flint stones was conducted with the use of the Flint computer programme created by the University of Science and Technology, Kraków. Apart from macroscopic and microscopic features, the study also yielded the results of chemical analysis by atomic absorption using an SP90 PYE Unicam spectrometer.

\section{Results}

The macroscopic analysis aimed to establish the statistical density of occurrence of particular petrographic types of boulders from long barrow
3. It was concluded that two types of granitoids pink and grey - prevail. They constitute $c a 70 \%$ of the studied boulders of the construction of long barrow 3 (Figs 3, 4). The comparison of the result with the analysis of Chachlikowski $(1997,2013)$ indicates that granitic rocks were preferred as raw material for stone wall constructions. In Kuyavia, granitoid erratic stones constitute up to $40 \%$ of the overall petrographic types of Scandinavian rocks (Chachlikowski 2013) (Fig. 5).

Microscope research indicates that the most common granitoid is pink alkali feldspar granite with quartz and biotite (Fig. 6).

Field observations of stones found in the long barrow construction indicate that some were processed by means of a "flaking" technique, and most probably by a rock-cutting and drilling technology.

Multiple boulders bear traces of "flaking". It is difficult to establish whether they were chipped in order to obtain stones of a particular shape, or with a view to using the obtained flakes for certain purposes. Observations of negative scars (traces of removed "flakes") indicate two types of origin of "flaking" structures: older and younger. They are easily recognisable by the extent of the patina on "dorsal" surfaces. The older type is covered by a clearly visible layer of patina, but it is much thinner and less developed than the primary patina that overlays the unprocessed sections of the stones. The younger generation has been recognised in fresh, almost unpatinated "flaking" with some vestigial patina. This proves that the "flaking" is not contemporary (Fig. 7A, B).

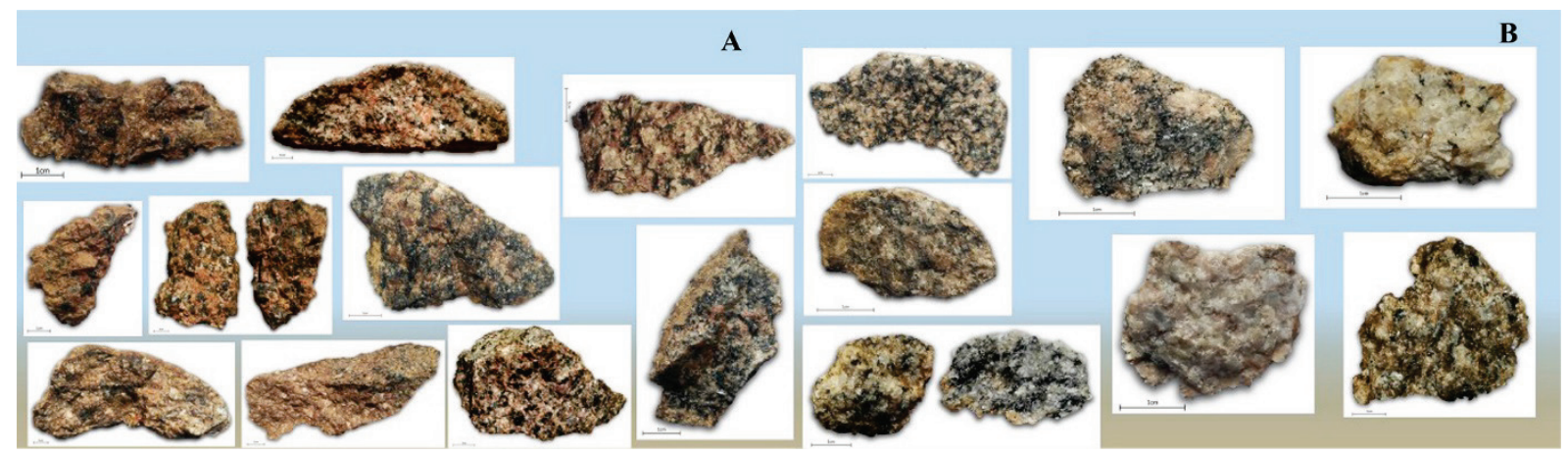

Fig. 3. Granitoid samples used for the stone wall construction of long barrow No. 3 at Wietrzychowice

A. Pink granites, B. Grey granites 


\section{Percentage of particular rock types in long barrow no 3}

\begin{tabular}{|c|c|}
\hline Type of rock & Number \\
\hline Pink granitoid & 47 \\
\hline Grey granitoid & 16 \\
\hline Granite-gneiss & 8 \\
\hline Quartzite & 6 \\
\hline Amphibolite & 3 \\
\hline Total & 80 \\
\hline
\end{tabular}

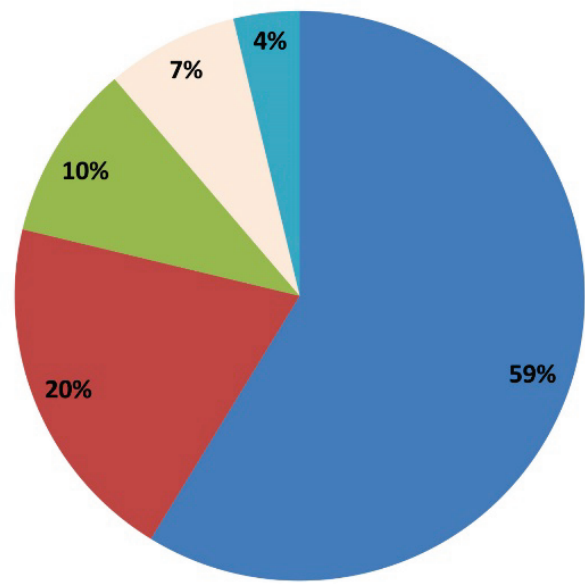

- Pink granitoid

Grey granitoid

- Granite-gneiss

Quartzite

Amphibolite

Fig. 4. Petrographic composition identification of the boulders from long barrow No. 3

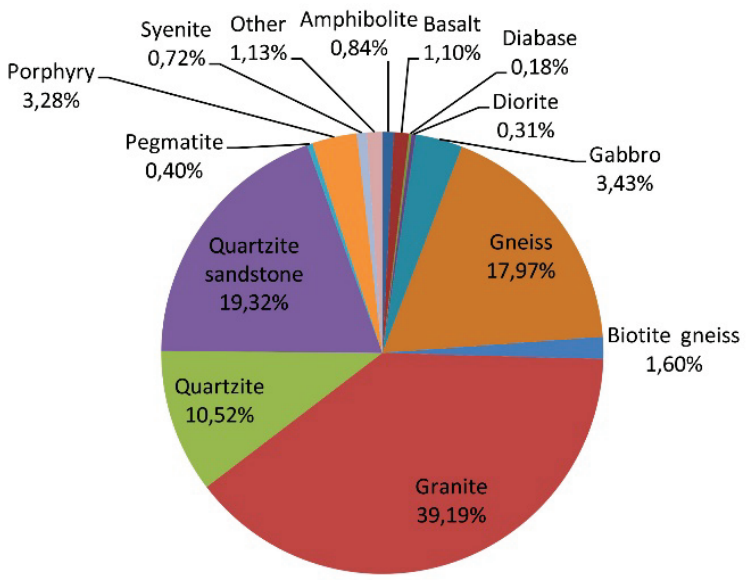

Percentage of erratic raw material in the region of Kuyavia

Overall record (number- specimens, percentage) of erratic stone examined in the region of Lubusz Land and Kuyavia

\begin{tabular}{|c|c|c|c|c|c|c|c|c|c|c|c|c|c|c|c|}
\hline $\begin{array}{l}\text { Location of } \\
\text { samples }\end{array}$ & 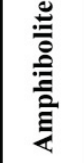 & 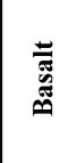 & 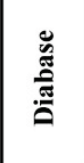 & & 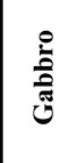 & 窇 & 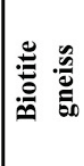 & 苞 & 菢 & 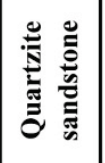 & 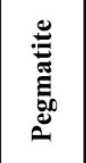 & 总 & 节 & 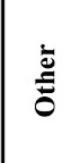 & है \\
\hline \multirow{2}{*}{ Lubusz Land } & 126 & 129 & 18 & 17 & 527 & 1326 & 161 & 5654 & 1623 & 3472 & 46 & 614 & 54 & 3 & 13770 \\
\hline & $0,92 \%$ & $0,94 \%$ & $0,13 \%$ & $0,12 \%$ & $3,83 \%$ & $9,63 \%$ & $1,17 \%$ & $41,06 \%$ & $11,79 \%$ & $25,21 \%$ & $0,33 \%$ & $4,46 \%$ & $0,39 \%$ & $0,02 \%$ & $100 \%$ \\
\hline \multirow{2}{*}{ Kuyavia } & 213 & 278 & 46 & 79 & 867 & 4543 & 404 & 9905 & 2660 & 4884 & 101 & 830 & 181 & 285 & 25276 \\
\hline & $0,84 \%$ & $1,10 \%$ & $0,18 \%$ & $0,31 \%$ & $3,43 \%$ & $17,97 \%$ & $1,60 \%$ & $39,19 \%$ & $10,52 \%$ & $19,32 \%$ & $0,40 \%$ & $3,28 \%$ & $0,72 \%$ & $1,13 \%$ & $100 \%$ \\
\hline \multirow{2}{*}{ Total } & 339 & 407 & 64 & 96 & 1394 & 5869 & 565 & 15559 & 4283 & 8356 & 147 & 1444 & 235 & 288 & 39046 \\
\hline & $0,87 \%$ & $1,04 \%$ & $0,16 \%$ & $0,25 \%$ & $3,57 \%$ & $15,03 \%$ & $1,45 \%$ & $39,85 \%$ & $10,97 \%$ & $21,40 \%$ & $0,38 \%$ & $3,70 \%$ & $0,60 \%$ & $0,74 \%$ & $100 \%$ \\
\hline
\end{tabular}

Fig. 5. Tabular and graphic comparison of the results of petrographic research of Scandinavian erratic stones after Chachlikowski (2013) 


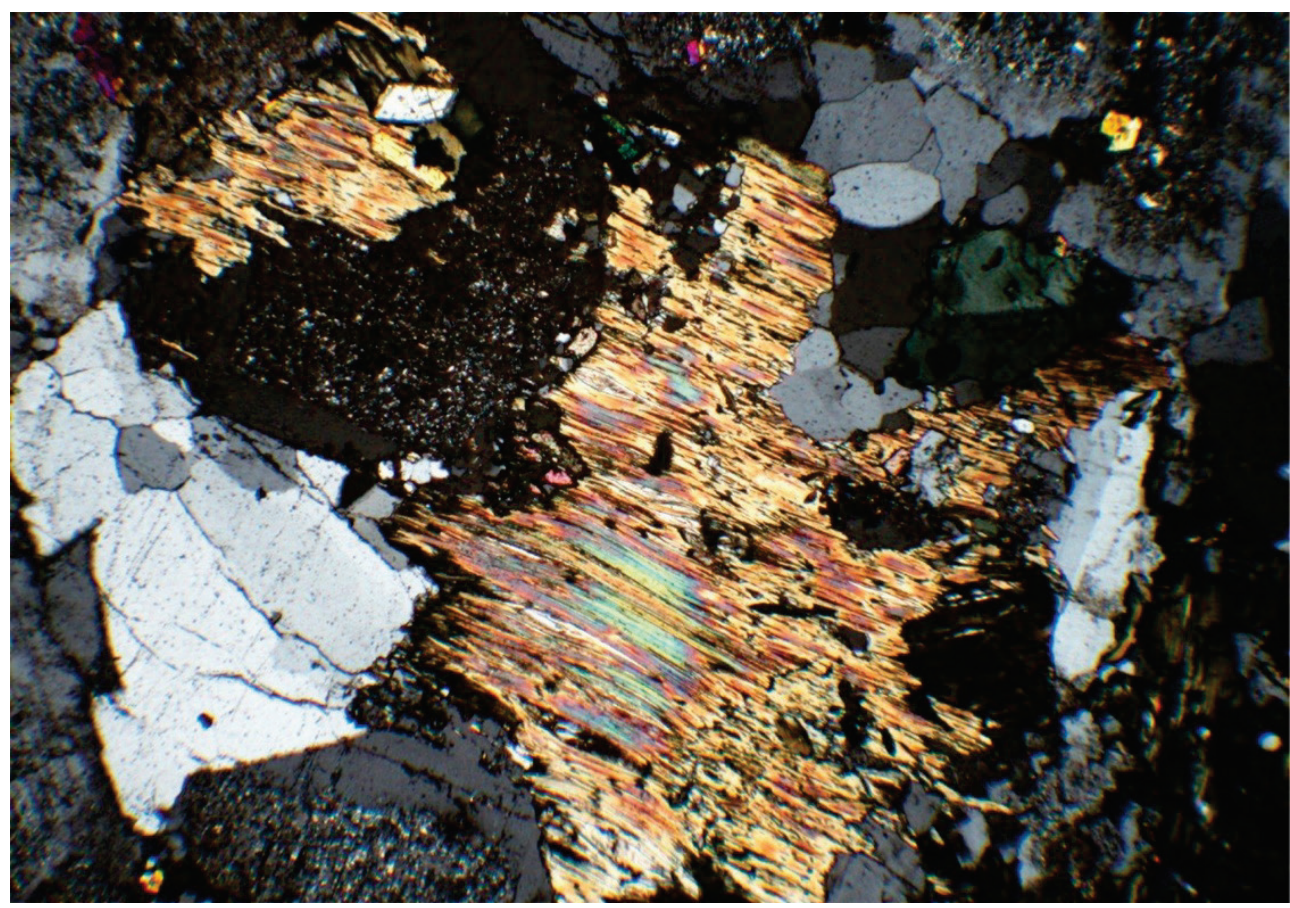

Fig. 6. Granite from boulder No. 45

visible crystals of K-feldspar, quartz and colourful lamellae of biotite; polarising microscope, PolaroidX, magnification $40 \times$

Detailed observation of the surfaces of stones of all barrows at Wietrzychowice has revealed a considerable number of boulders with one (more rarely, two) completely flat surfaces. They do not normally occur on Scandinavian erratic stones, which are characterised by a diversified, though not geometrical, rounded shape. The mentioned flat surfaces (Fig. 7C-F) are occasionally quite damaged by weathering processes and they are differently patinated (much more faintly) than primary surfaces of erratic stones (Fig. 7G).

The previously mentioned flat surfaces bear traces of a different extent of rock cutting, visible in the form of parallel grooves that are similar in shape to one another and lie at regular distances from one another (Fig. $7 \mathrm{H}, \mathrm{I})$. The traces have a different state of preservation and they are often faintly discernible, especially on surfaces covered with moss.

Stones with flat surfaces occasionally bear traces of "flaking". These traces are younger than the traces of rock cutting because they occur over the "cut" surfaces.

Only one examined boulder bears a hole made by a drilling technology (Fig. 8). This hole was several centimetres long and its walls were almost completely void of patina - and much lighter than the natural surfaces of the rock.

The observations of flat, "cut" surfaces revealed that the grooves are in some places consid- erably damaged and their walls are uneven (Fig. 9A, B). A similar situation can be observed on the inner wall of the hole drilled in the rock (Fig. 9C). Traces of drilling on the walls of the hole are at some points almost invisible, even though the surface of the hole wall is light and unpatinated (Fig. 9A, B) in comparison with the natural surface of the rock. This is definite proof that the hole is much younger than the patinated stone surface.

Microscope observations of the walls of grooves on flat surfaces turned out to be very interesting. They indicate that the overlying layer of patina is much fainter, thinner and less developed, and thus younger than the patina covering the surface of erratic stones (Fig. 9). This observation attests that the grooves are not the result of glacial processes (polishing of stones against one another), but are much younger because they damaged the old patina.

The analyses of scanning pictures of the cutting traces of boulders (Fig. 9E, F) indicate that they did not resist the destructive weathering processes. The processes that caused greatest damage include freezing and thawing, which loosened the damaged structure of the rock surface. Undoubtedly, moss and lichen overgrowing stone surfaces also played a destructive role, making the primary shape of the cutting trace no longer visible. 

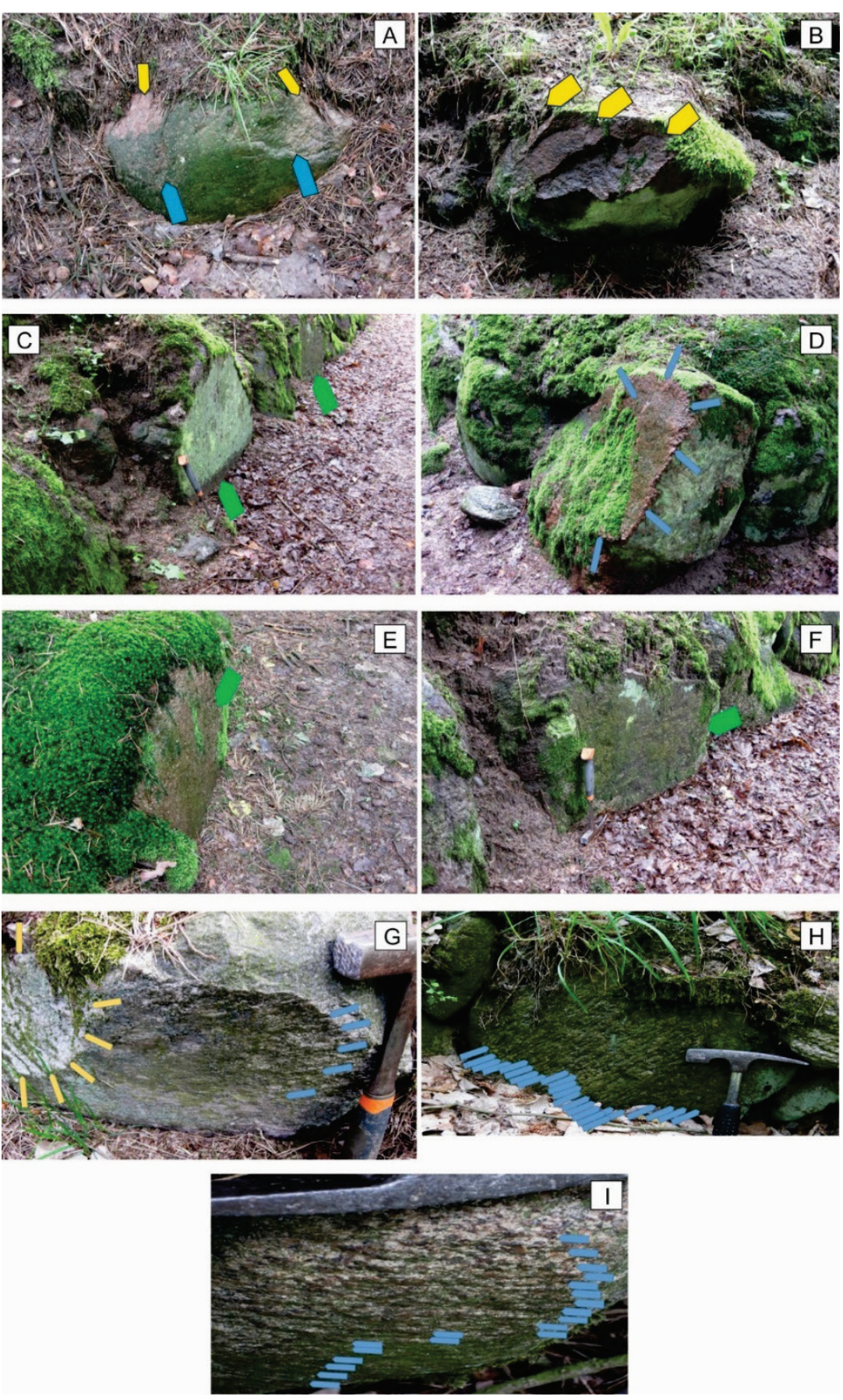

Fig. 7. Examples of processed Scandinavian erratic stones from long barrow No. 3

A. Granitoid processed by means of "flaking" technique (blue arrows - older negative scars, yellow arrows - younger negative scars)

B. Feldspar granite-gneiss with traces of "flaking" (yellow arrows - younger generation of processing)

C. Grey granitoid with flat "cut" surface (green arrows - direction of cutting)

D. K-feldspar granite with unpatinated cut surface (marked with blue arrows)

E. Red granitoid with one "cut" flat surface (green arrow - direction of cutting)

F. Pink granitoid with one surface obtained as a result of cutting (marked with arrow)

G. Grey granitoid with traces of cutting technology (yellow arrows - natural surface of the erratic stone with a light patina, blue arrows - processed surface)

H. Pink granitoid with weathered surface with traces of cutting (blue arrows - directions of the traces of cutting)

I. Grey granitic with traces of cutting (marked with blue arrows) 


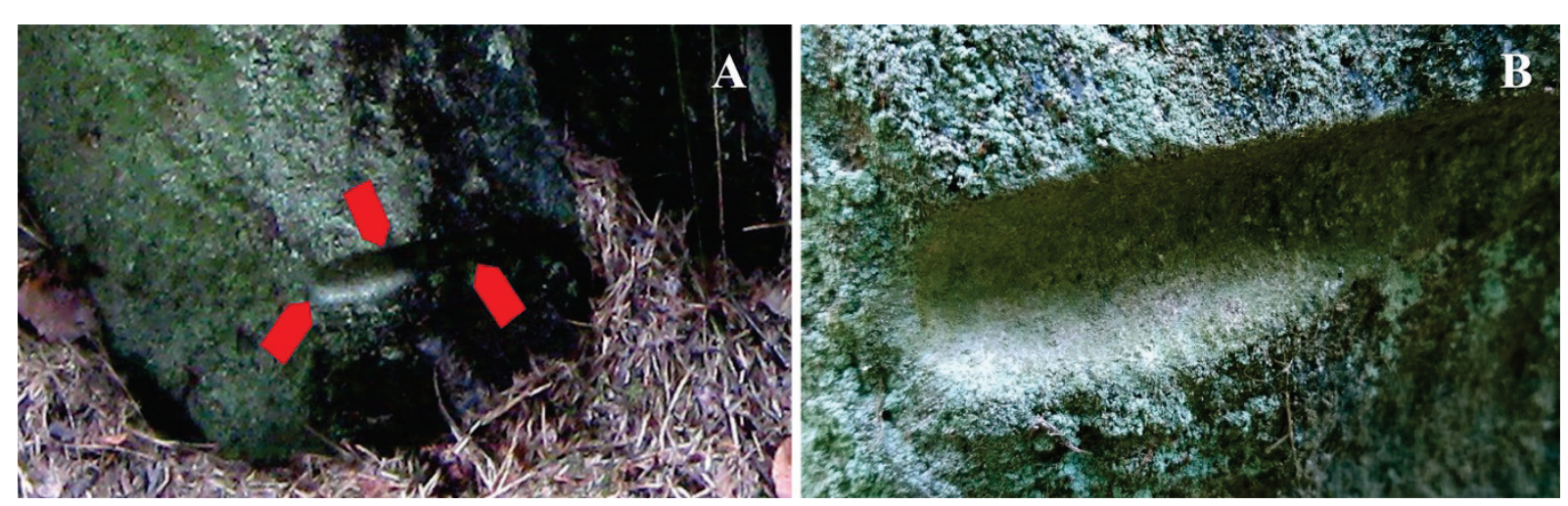

Fig. 8. Boulder from long barrow No. 3 with traces of drilling (marked with arrows)

A. General view

B. An enlargement of traces of drilling
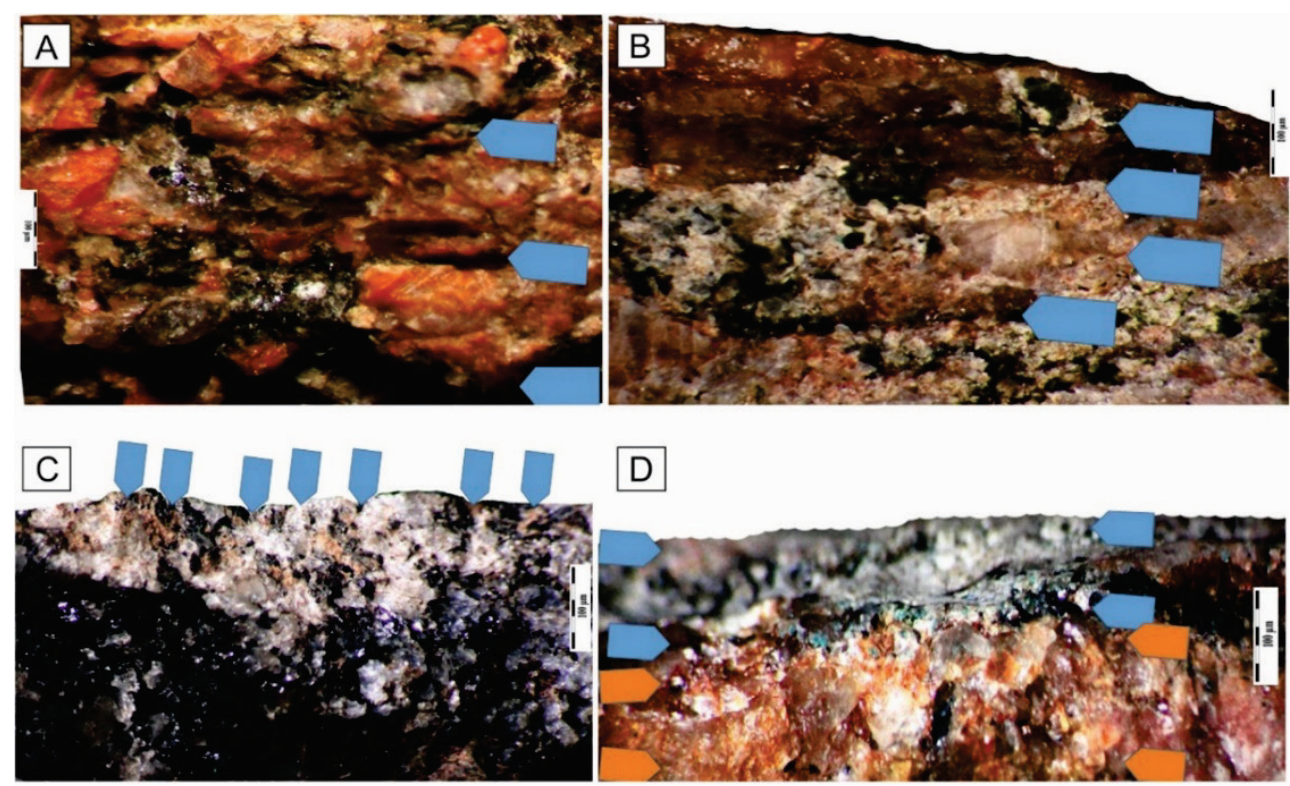

D
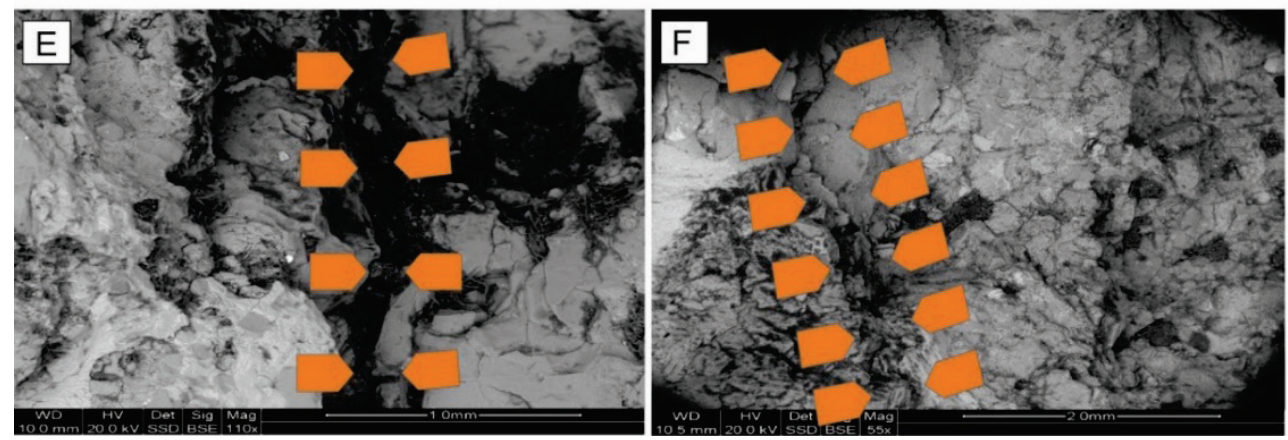

Fig. 9. Microscopic traces on surfaces of boulders from long barrow No. 3 (A-D - binocular microscope, E-F - scanning microscope)

A. Traces of grooves (sample 2)

B. Traces of grooves (sample 8)

C. Wall of drilled hole - light upper part of the photo, patinated surface - dark bottom part of the photo (arrows - traces of grooves)

D. Groove wall on surface of cutting (blue arrows - patinated, old surface of granitic rock; orange arrows - younger, almost unpatinated surface of a groove wall across the patina)

E, F. Traces of cutting distorted by secondary weathering 
Chemical analyses of walls of cutting traces (Table 1,2) indicate a constant presence of titanium (in addition to other elements). Its amount is not high, but its presence prevails in all the analysed points of the walls of the cutting trace.

Granitoids like the ones that underwent analyses may bear traces of low amounts of minerals of titanium (ilmenite, rutile, etc.); however, they occur in rocks as spots of crystals. In the analysed places, titanium does not form separate mineral spots, but it is present in a scattered form. Titanium co-occurs here with vestigial amounts of iron, also present in scattered form. The mineralogical and geochemical explanation of this type of element occurring in the cutting traces of boulders is hard to provide at this stage of research.

Table 1

Results of chemical analyses of the walls of the cutting trace in the pink granite, conducted in three different places

\begin{tabular}{|c|c|}
\hline Element & $\mathrm{Wt} \%$ \\
\hline $\mathrm{C}$ & 10.13 \\
\hline $\mathrm{O}$ & 36.56 \\
\hline $\mathrm{Na}$ & 0.87 \\
\hline $\mathrm{Mg}$ & 0.24 \\
\hline $\mathrm{Al}$ & 9.96 \\
\hline $\mathrm{Si}$ & 29.28 \\
\hline $\mathrm{P}$ & 0.12 \\
\hline $\mathrm{Si}$ & 0.15 \\
\hline $\mathrm{K}$ & 11.55 \\
\hline $\mathrm{Ca}$ & 0.43 \\
\hline $\mathrm{Ti}$ & 0.29 \\
\hline $\mathrm{Fe}$ & 0.24 \\
\hline
\end{tabular}

\begin{tabular}{|c|c|}
\hline Element & $\mathrm{Wt} \%$ \\
\hline $\mathrm{C}$ & 62.47 \\
\hline $\mathrm{O}$ & 28.04 \\
\hline $\mathrm{Na}$ & 0.22 \\
\hline $\mathrm{Mg}$ & 0.09 \\
\hline $\mathrm{Al}$ & 0.78 \\
\hline $\mathrm{Si}$ & 5.62 \\
\hline $\mathrm{P}$ & 0.33 \\
\hline $\mathrm{Si}$ & 0.56 \\
\hline $\mathrm{K}$ & 0.22 \\
\hline $\mathrm{Ca}$ & 0.74 \\
\hline $\mathrm{Ti}$ & 0.15 \\
\hline $\mathrm{Fe}$ & 0.78 \\
\hline
\end{tabular}

\begin{tabular}{|c|c|}
\hline Element & Wt $\%$ \\
\hline $\mathrm{C}$ & 17.41 \\
\hline $\mathrm{O}$ & 46.41 \\
\hline $\mathrm{Na}$ & 0.55 \\
\hline $\mathrm{Mg}$ & 0.13 \\
\hline $\mathrm{Al}$ & 0.91 \\
\hline $\mathrm{Si}$ & 33.10 \\
\hline $\mathrm{P}$ & 0.20 \\
\hline $\mathrm{Si}$ & 0.20 \\
\hline $\mathrm{K}$ & 0.26 \\
\hline $\mathrm{Ca}$ & 0.35 \\
\hline $\mathrm{Ti}$ & 0.10 \\
\hline $\mathrm{Fe}$ & 0.37 \\
\hline
\end{tabular}

Table 2

Results of chemical analyses of the walls of the "cutting trace" in the grey granite, conducted in three different places

\begin{tabular}{|c|c|}
\hline Element & $\mathrm{Wt} \%$ \\
\hline $\mathrm{C}$ & 37.04 \\
\hline $\mathrm{O}$ & 31.54 \\
\hline $\mathrm{Na}$ & 1.14 \\
\hline $\mathrm{Mg}$ & 0.12 \\
\hline $\mathrm{Al}$ & 3.34 \\
\hline $\mathrm{Si}$ & 22.55 \\
\hline $\mathrm{P}$ & 0.00 \\
\hline $\mathrm{Si}$ & 0.27 \\
\hline $\mathrm{K}$ & 1.89 \\
\hline $\mathrm{Ca}$ & 0.84 \\
\hline $\mathrm{Ti}$ & 0.33 \\
\hline $\mathrm{Fe}$ & 0.92 \\
\hline
\end{tabular}

\begin{tabular}{|c|c|}
\hline Element & Wt \% \\
\hline $\mathrm{C}$ & 17.16 \\
\hline $\mathrm{O}$ & 34.92 \\
\hline $\mathrm{Na}$ & 0.30 \\
\hline $\mathrm{Mg}$ & 0.06 \\
\hline $\mathrm{Al}$ & 7.91 \\
\hline $\mathrm{Si}$ & 26.09 \\
\hline $\mathrm{P}$ & 0.11 \\
\hline $\mathrm{Si}$ & 0.16 \\
\hline $\mathrm{K}$ & 12.18 \\
\hline $\mathrm{Ca}$ & 0.40 \\
\hline $\mathrm{Ti}$ & 0.24 \\
\hline $\mathrm{Fe}$ & 0.48 \\
\hline
\end{tabular}

\begin{tabular}{|c|c|}
\hline Element & $\mathrm{Wt} \%$ \\
\hline $\mathrm{C}$ & 24.40 \\
\hline $\mathrm{O}$ & 32.70 \\
\hline $\mathrm{Na}$ & 0.28 \\
\hline $\mathrm{Mg}$ & 0.30 \\
\hline $\mathrm{Al}$ & 1.51 \\
\hline $\mathrm{Si}$ & 38.98 \\
\hline $\mathrm{P}$ & 0.00 \\
\hline $\mathrm{Si}$ & 0.04 \\
\hline $\mathrm{K}$ & 0.48 \\
\hline $\mathrm{Ca}$ & 0.33 \\
\hline $\mathrm{Ti}$ & 0.35 \\
\hline $\mathrm{Fe}$ & 0.65 \\
\hline
\end{tabular}

With the use of the geological map by Roman (2019), several regions were designated as containing boulders that may have been used as a local stone raw material for megalith constructions. It was also supposed that areas where gravels occur may contain flints. During the 
reconnaissance surveys, Cretaceous and Jurassic flint stones were discovered on the terrain surface as a so-called secondary deposit - in the Szczkówek region and on the fields in the vicinity of the Wietrzychowice long barrows, as well as during excavations at the Osiecz and Śmieły sites (Fig. 1).

Flint stones from the Szczkówek and Wietrzychowice areas constitute $c a 1 \%$ of material among erratic stones. Cretaceous flint stones prevail. They are grey in colour and usually covered with a light, occasionally white "cold" pati- na (Fig. 10). The flint stones are compact, and susceptible to "flaking" technology. They are composed of chalcedony with colourful micrograins of calcite and a low admixture of opal and quartz (Fig. 11). Their full description is presented in Table 2, based on the sample of one flint stone (F1). On the basis of the microscope examination, it can be concluded that they have a typical microcrystalline texture. Some of them bear a thick cortex, which indicates shortdistance transportation during the last glacial period.
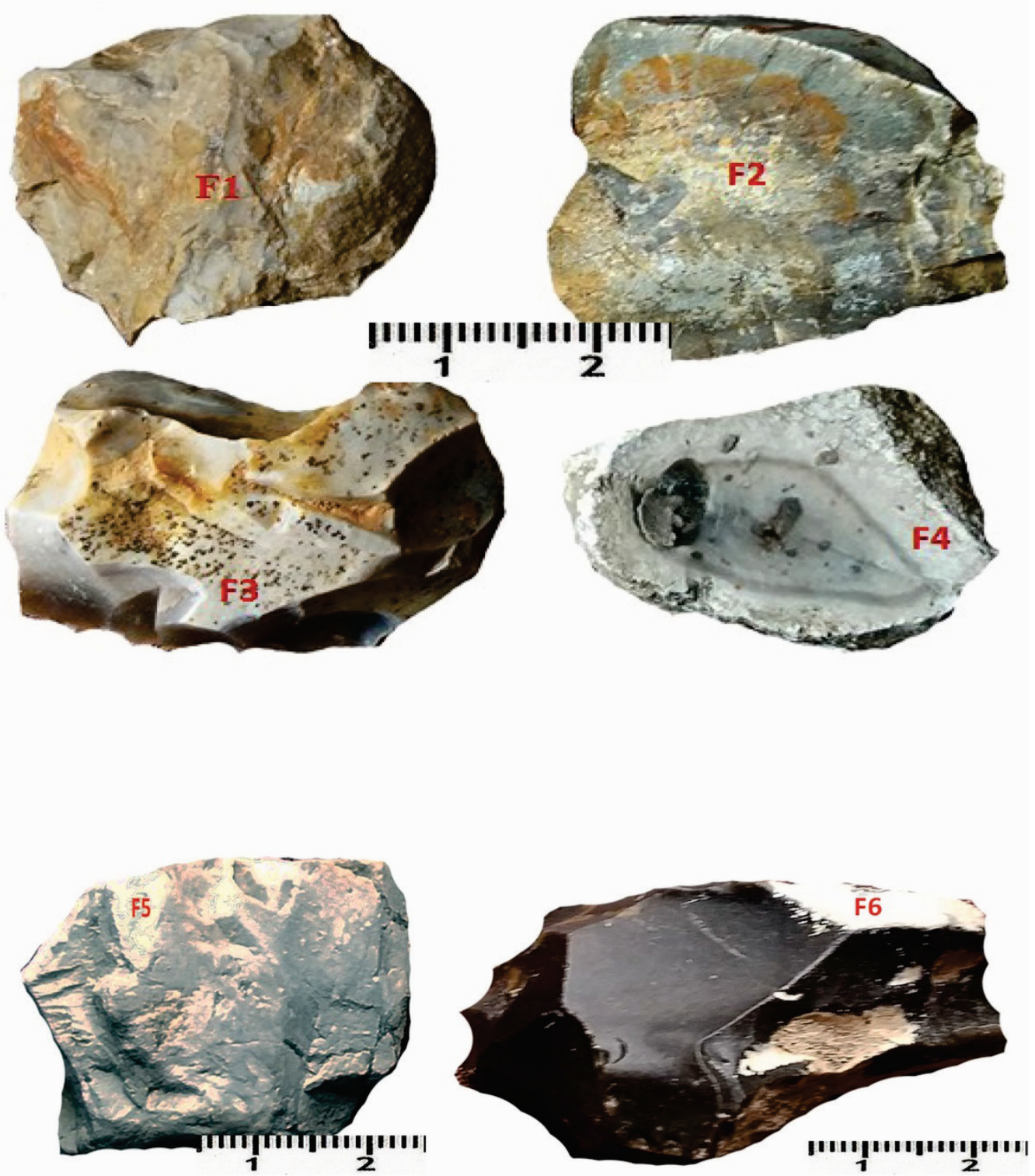

Fig. 10. Flint pebbles from glaciofluvial gravels, from the Szczkówek region (F1 F2 F3 F4) and Wietrzychowice region (F5, F6) (see Fig. 1) 

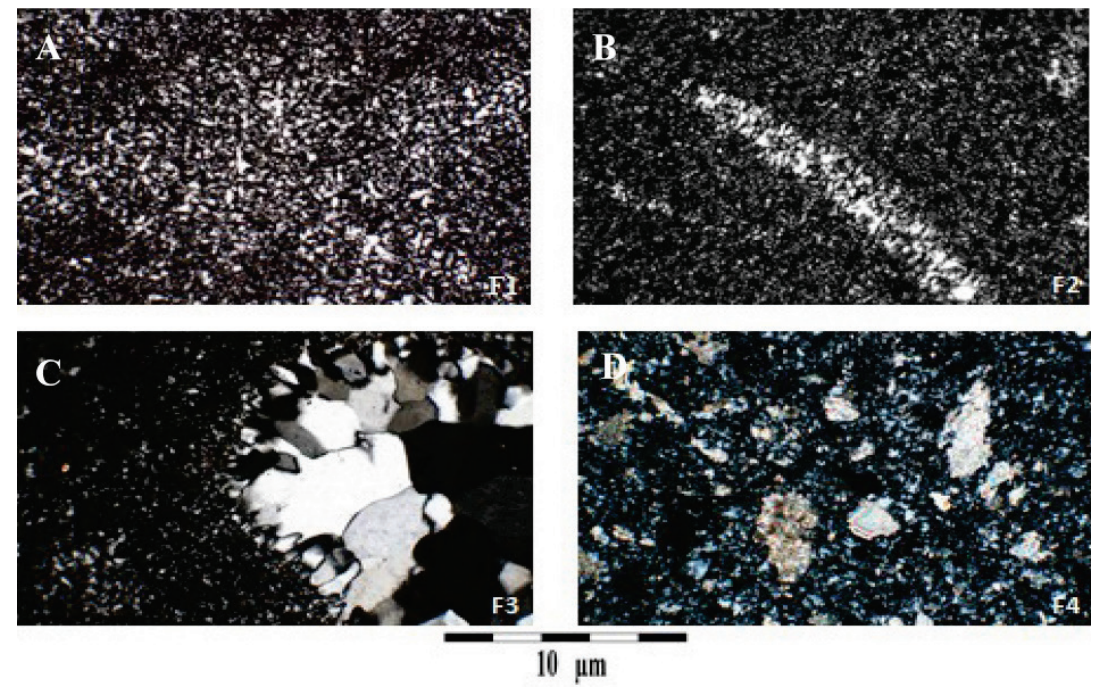

Fig. 11. Microscope pictures of the texture of Cretaceous flint (A, B, C) and Jurassic flint (D)
A. Chalcedony-opal structure
B. Chalcedony sponge needle-like spicules in chalcedony-opal dough
C. Cluster of larger, secondary crystals of chalcedony against a chalcedony-opal background
D. Chalcedony with admixtures of colourful grains of calcite; polarising microscope, Polaroid X

\section{Conclusions}

On the basis of both field and laboratory research of flint stones from the area of Wietrzychowice, it can be concluded that they are present in local gravels. Their amount among stones of Scandinavian origin does not exceed $1 \%$. They are of rather poor quality from the point of view of raw material and technology. However, it is possible that they have been processed, particularly by means of "flaking" technique. It can be assumed that they were more abundant when the local Stone Age communities were active. Their amount decreased due to their use to make tools.

At this stage of study it can be concluded that the studied boulders of the megalith constructions at Wietrzychowice were deliberately selected from the Scandinavian material brought here by the glacier.

Some studied boulders from the stone wall construction of long barrow 3 were processed with the use of a "flaking" technique. Interestingly, the stones were processed twice by means of the same technique with a long time span in between. This is attested by a clear difference in patination on the negative scars left after "flaking".

Traces of cutting and drilling on some boulders are quite mysterious and difficult to explain. They are evidently younger than the primary "glacial" patina that occurs on erratic stones' surfaces. The traces may be contemporaneous with the construction period of the long barrows, but this theory is disputable. The examined traces have only been observed on the exterior surfaces of stones. The interior part of the boulders, i.e. from the side of the long barrows, has not been analysed. If the traces only occur on exterior surfaces of the stones, they may have been processed after the long barrow's construction. It remains to be solved when, why and how the long barrow was made.

\section{References}

Chachlikowski P. 1997. Kamieniarstwo późnoneolitycznych społeczeństw Kujaw. Uniwersytet im. A. Mickiewicza, Poznań.

Chachlikowski P. 2013. Surowce eratyczne w kamieniarstwie społeczeństw wczesnoagrarnych Niżu Polskiego (IV-III tys. przed Chr.). Uniwersytet im. A. Mickiewicza, Poznań.

Jadczykowa I. 1970. Sprawozdanie z badań prowadzonych w latach 1967 i 1968 na stanowisku 1 w Wietrzychowicach, pow. Koło. Prace i Materiały Muzeum Archeologicznego i Etnograficznego $w$ Łodzi, Seria Archeologiczna 17: $125-$ 144.

Jadczykowa I. 1971. Sprawozdanie z końcowego etapu prac badawczych na neolitycznym cmentarzysku grobowców kujawskich w Wietrzychowicach, pow. Koło. Prace $i$ Materiaty 
Muzeum Archeologicznego i Etnograficznego w Lodzi, Seria Archeologiczna 18: 93-102.

Jaranowski M. 2019. Badania mineralogiczno-petrograficzne głazów w konstrukcjach megalitycznych kultury pucharów lejkowatych w Wietrzychowicach, gmina Izbica Kujawska. Praca inżynierska, Akademia Górniczo-Hutnicza im. Stanisława Staszica w Krakowie.

Jażdżewski K. 1936a. Groby kujawskie w Wietrzychowicach w pow. kaliskim (recte: kolskim!) (stan. 1). Z otchłani wieków 11(3): 52.

Jażdżewski K. 1936b. Olbrzymi grób kujawski w Wietrzychowicach. $Z$ otchtani wieków 11(10-11): $121-129$

Kittel P. 2017. Budowa geologiczna i geomorfologiczna obszaru. In: P. Papiernik, D.K. Płaza (eds) Park Kulturowy Wietrzychowice na europejskim szlaku megalitów. Wydawnictwo Fundacji Badań Archeologicznych Imienia Profesora Konrada Jażdżewskiego, nr 21, Łódź: 160167.
Papiernik P. 2016. Grobowce kujawskie w Wietrzychowicach i Gaju. Osiemdziesiąt lat badań archeologicznych. Zapiski Kujawsko-Dobrzyńskie 30: 13-30.

Papiernik P., Płaza D.K. 2017 (eds). Park Kulturowy Wietrzychowice na europejskim szlaku megalitów. Wydawnictwo Fundacji Badań Archeologicznych Imienia Profesora Konrada Jażdżewskiego, nr 21, Łódź.

Roman M. 2003. Rozwój rzeźby plejstoceńskiej okolic Gostynina. Acta Geographica Lodziensia 84.

Roman M. 2010. Rekonstrukcja lobu płockiego w czasie ostatniego zlodowacenia. Acta Geographica Lodziensia 96.

Roman M. 2019. Budowa geologiczna i sytuacja geomorfologiczna w rejonie Parku Kulturowego Wietrzychowice. Archiwum Fundacji Badań Archeologicznych Imienia Profesora Konrada Jażdżewskiego. 